\title{
An Experimental Investigation of The Dynamic Effects in Upper Drum Boiler Under Steam Mass Flow Rate Variation
}

\author{
Russul H. Mohammed (D), Hashim A. Hussein ${ }^{(D)}$, Ali H. Numan \\ Electromechanical Engineering Department, University of Technology, Baghdad, Iraq. \\ *Corresponding author Email: eme.19.47@grad.uotechnology.edu.iq
}

\section{H I G H L I G H T S}

- Rapid rise in the steam mass flow rate causes the increase in dynamic effects.

- The pressure disturbance in the boiler's upper drum cause mechanical effects.

- Drum level fluctuations cause interactions with the controls of boiler combustion.

- Interactions with the controls, resulting inefficient and dangerous operations.

\section{A R T I C L E IN F O}

Handling editor: Muhsin J. Jweeg

Keywords:

Dynamic Effects

Swell and Shrink

Water Tube Boilers

\begin{abstract}
A B S T R A C T
The dynamic effects in the "upper" drum of the boiler (mechanical's effects) are very complex problems and critical due to the pressure disturbance in the upper drum of the boiler. This work deals with an experimental investigation of the dynamic behavior of the boiler drum level system is reported from plant data (Al-Quds power plant) in Baghdad / Iraq under a particular condition of operating, and the mathematical equations of the boiler model variables explained and defined. The dynamic effects are investigated with increasing steam mass flow rate $(10 \%$ and $20 \%)$ at the outlet of the boiler. The results showed that the rapid rise in the rate of steam mass flow causes the dynamic effects to increase (shrink and swell) by $15 \%$, rates of evaporation and thus causes an increase in the volume of water inside the upper drum boiler that causes overheating in the tubes.
\end{abstract}

\section{Introduction}

Boilers are closed containers in which water is transferred to steam under pressure and through the application of heat. The furnace of a boiler can convert the chemical energy in the fuel to heat, and it is the function of the boiler to transfer this heat to the contained water in the most efficient technique. This heat is transferred by radiation, conduction, and convection to the water in the boiler [1]. The relative percentage of each depends on the type of boiler, the heat transfer surface built for, and the type of fuel. In the boiler drum, the water-steam interface occurs where the boiler drum level in the safe operation of a boiler is a critical variable [2]. The Low-level water in the drum makes increasing in the steam, and when the water level high that causes carryover water into the steam header and decreasing the steam in the drum [3]. If the amount of water in the upper drum reaches the limits, the boiler water brings into the turbine, super heater, and this can cause harm resulting in comprehensive repair costs, either the turbine or the boiler failures [4]. The decline in the pressure reasons to a small portion of the saturated water in the boiler immediately vaporizes; this produces a large magnitude of boil-up from most of the boiler tubes. So that, the level controller sensing an elevation in the level of the pressure cycles of the drum will be caused variation in drum level [5].

Steam generation water distribution management is a critical issue that must be considered for boiler safety and reliability. Boiler shutdowns are common due to poor management. One of the most serious issues of boiler technology is water distribution in natural circulation drum boilers [6,2]. Poor water circulation may lead to tube rupture, which can result in an unplanned boiler shutdown, disrupting plant operations. Weak circulation can be caused by operational issues such as rapid increases in boiler load, which causes rapid increases in heat flux as a result of rapid increases in fuel flow speeds. Due to the non-uniformity of heat flux transmission in the furnace, each boiler tube faces different heating conditions. Poor circulation water has been blamed for several boiler explosions in recent years. So, to cool the tubes that constitute the boiler walls, proper water circulation is needed [7]. Figure 1 shows the schematic diagram of the upper drum. 


\section{Water level variation}

Under any load inside the boilers, the drum water, mud drums, and boiler tubes cohabit with the generated steam bleb. The resulting development of steam flow from the drum causes a decrease in pressure if the request steam is unexpectedly increased [8]. Because the drum pressure function is the rate of steam production, the pressure drop would immediately cause additional steam to be produced. This implies that the water "inventory" of the steam boiler is accompanied by additional steam bubbles as the steam rises under the water surface within the boiler to water ratio [9].

The drum level increases swell until the rate of the supplementary steam generation stabilizes due to the steam already having a greater specific volume than water. Once the stabilizing rate has been achieved, unless the feed water flows rise immediately, the lack of equilibrium of mass movement from both the feed water and steam flows would lead to the drum level dropping. And this makes managing the drum level difficult [4,10].

The decline in the pressure reasons to a small portion of the saturated water in the boiler immediately vaporizes; this produces a large magnitude of boil-up from most of the boiler tubes. So that, the level controller sensing an elevation in the level of the pressure cycles of the drum will be caused variation in drum level. Can describe the linearized behavior of a wet surface $\left(A_{d}\right)$ at the operation level and the perversion in the drum level (L) we measure from its normal operating level is [11]:

$$
L=\frac{V_{w d}+V_{s d}}{A_{d}}=L_{s}+L_{w}
$$

Figure 2 shows the variation in Drum level, if the rush order for steam decreases instantly the same effect happens, but in the opposite direction. Drum pressure rises rapidly in this situation, reducing the steam production and steam-to-water ratio $[12,7]$. This shows the initial declines in the drum level before the new steam-generating rate supplies stabilize. Whenever the stem rate is stabilized, the drum level will start rising, except if the feed water stream is decreased to settle with the latest steam flow rate immediately [13].

\section{Swelling and shrinking phenomena}

The downstream mechanism regulates the flow of steam from the boiler. The strain in the steam drum and boiler circuit is affected by a sudden rise or decrease in steam flow. The boiling point and density of water and steam will both change as the pressure changes. The amount in the steam drum will quickly increase or decrease as a result of these simultaneous reactions $[14,15]$. The swell and shrink reactions are the rise and fall of water level caused by pressure changes.The swell and shrink reactions are in the opposite direction of the boiler's natural activity. As a result, swell and shrink reactions wreak havoc on steam drum level power. The pressure in the boiler circuit will rise if the steam output from the boiler is abruptly decreased [16]. Due to a higher inflow than outflow, the drum level will initially shrink and then raise as the pressure rises. As the steam output from the boiler is abruptly raised, the opposite is real. Pressure fluctuations caused by unstable energy supply to the boiler will also induce the same swell and shrink reactions, making steam drum level control incredibly difficult [17].

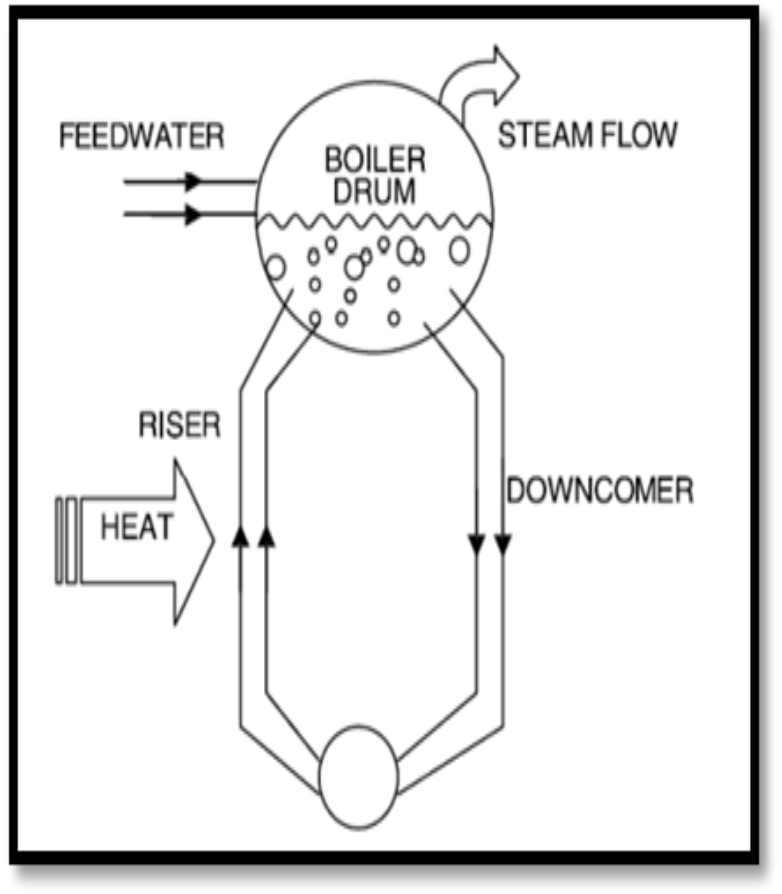

Figure 1: Schematic diagram of the upper drum [1].

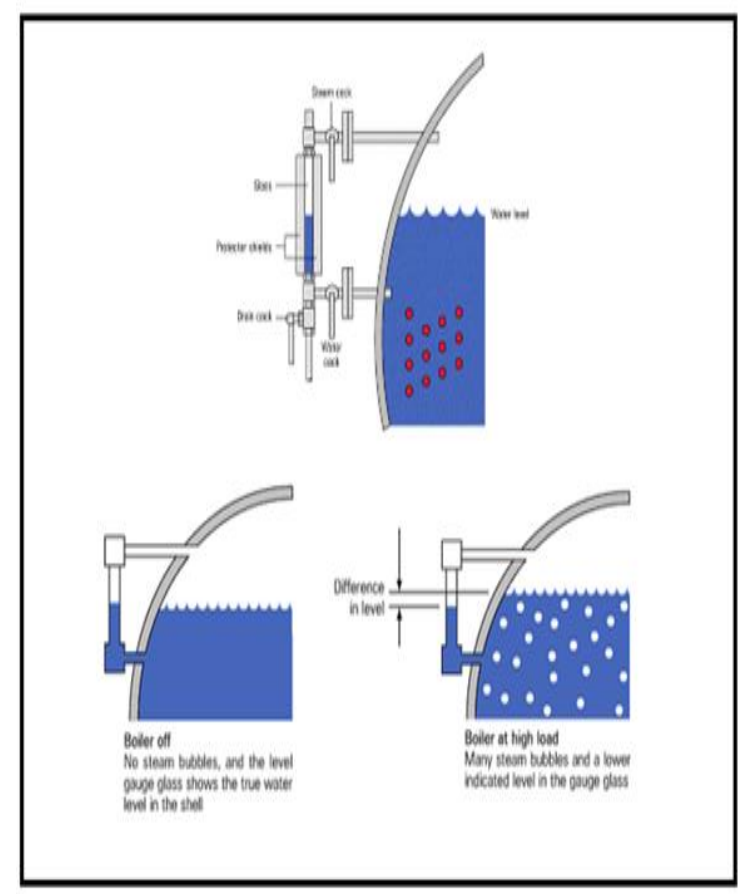

Figure 2: Drum level variation [9]. 


\section{Mathematical formulation}

It is very difficult to achieve the solution of mathematical equations as a synthesis of the mathematical description. In several phenomena, the number of variables, nonlinearities, and uncertainties contribute to the complexity of the problem [18]. The governing equations consist of the preservation of the total system's mass and energy, the phase shift in the drum boiler, including the volumes of water and steam within the drum boiler, and the rate of steam condensation and flow circulation in the riser-down comer loop, which controls the mass, energy and momentum transport.

The equation simultaneously solved using the explicit method by time step 0.3 second for a total time of 400 seconds $[11,19]$.

$$
\begin{gathered}
\dot{m}_{w}-\dot{m}_{s}=a_{11} \frac{d V_{w t}}{d t}+a_{12} \frac{d P}{d t} \\
\dot{Q}+m_{w} h_{w}-m_{s} h_{g}=a_{21} \frac{d V_{w t}}{d t}+a_{22} \frac{d P}{d t} \\
a_{11}=\rho_{f}-\rho_{g}=\rho_{f g} \\
a_{12}=V_{w t} \frac{\partial \rho_{f}}{\partial p}+v_{s t} \frac{\partial \rho_{g}}{\partial p} \\
a_{21}=\rho_{f} h_{f}-\rho_{g} h_{g} \\
a_{22}=V_{w t}\left(h_{f} \frac{\partial \rho_{f}}{\partial p}+\rho_{f} \frac{\partial h_{f}}{\partial p}\right)+V_{s t}\left(h_{g} \frac{\partial \rho_{g}}{\partial p}+\rho_{g} \frac{\partial h_{g}}{\partial p}\right)-V_{t}+M C_{P} \frac{\partial T_{S}}{\partial P} \\
\dot{m}_{s}=\dot{m}_{w} \\
\dot{m}_{s}\left(h_{g}-h_{w}\right)=\dot{Q}
\end{gathered}
$$

Equations (8 and 9) are representing the equilibrium conditions. All parameters are measured and calculated such as, drum pressure, steam mass flow rate, drum volume, riser, and downcomer volumes, water surface area, feed water temperature, and thermal conductivity of the pipe material. There are many constants according to the boundary conditions are taken from power plant characteristics.

\section{Experimental procedure}

The experimental process of this work was applied to the steam generator of the boiler (water tube) in Baghdad / Iraq (AlQuds power plant) model (szs20-1.0-210y). Table I shows the technical characteristics of the steam plant generator. All the parameters were determined when the plant was in a state of thermal equilibrium, and other data was reported from the technical characteristics sheet of the steam generator. Figure 3 shows the water tube boiler in (Al-Quds power plant).

The experimental operation work requires the analysis of the fundamental parameters as follows:

\subsection{Drum pressure measurement}

Figure 4 shows the steam generation unit's drum pressure gauge. It varies depending on the firing rate and steam demand (turbine load), so to calculate the drum strain, we start the plant at a steady firing rate and let it run until it stabilizes. While the steam pressure and temperature in different points of the circuit, as well as the temperature of the cooling water at the condenser's outlet remain constant. When the drum pressure has stabilized, the following adjustments are used to determine the drum pressure: - (i) raising the steam load by $10 \%$, (ii) increasing the steam load by $20 \%$. The drum pressure is measured with time at each transition.

\subsection{Drum Level Measurement}

The drum level of the steam generation unit has a complex engineering design (90 mm gauge "length glass") [Figure 5]. Reading the drum level directly from the glass gauge to record the drum level's reaction to the firing rate, synchronization, measuring the drum level to increase the steam mass flow rate ("10 percent and 20 percent") at the outlet of the boiler. This represents the swelling phenomenon. The same process is repeated in the opposite direction, drum level reaction with the following modifications: (i) reducing the steam load by $10 \%$, and (ii) reducing the steam load by $20 \%$. This represents of shrinkage phenomenon. Liberalized behavior can be represented by the wet surface $\left(A_{d}\right)$ at the functional level may be viewed.

Table 1: The technical characteristics of steam plant generator

\begin{tabular}{ccccc}
\hline $\begin{array}{c}\text { Normal } \\
\text { capacity }\end{array}$ & $\begin{array}{c}\text { Steam } \\
\text { pressure }\end{array}$ & $\begin{array}{c}\text { Steam } \\
\text { temperature }\end{array}$ & $\begin{array}{c}\text { Feed water } \\
\text { temperature }\end{array}$ & $\begin{array}{c}\text { Fuel } \\
\text { type }\end{array}$ \\
\hline $21 \mathrm{Ton} / \mathrm{h}$ & $10 \mathrm{bar}$ & $191.61^{\circ} \mathrm{C}$ & $120^{\circ} \mathrm{C}$ & $\mathrm{LDO}$ oil \\
\hline
\end{tabular}




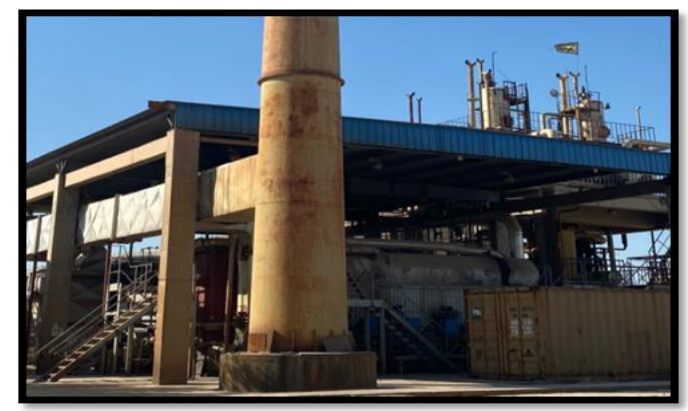

Figure 3: The water tube boiler in (Al-Quds power plant) Baghdad / Iraq.

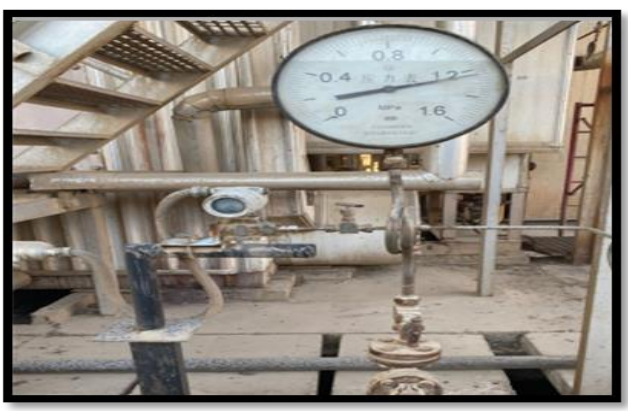

Figure 4: The gauge of drum pressure in the (Al-Quds power plant).

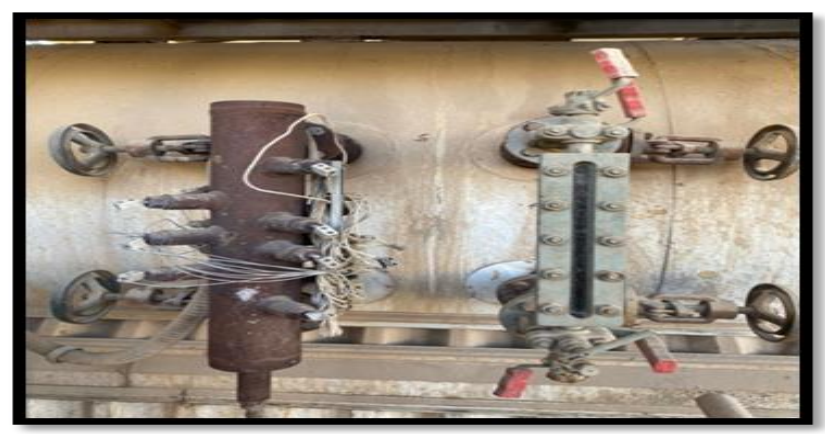

Figure 5: The gauge of the water level in the (Al-Quds power plant).

\subsection{Fuel level measurement}

The amount of fuel (LDO oil) in the tank was determined at normal operating and the reaction of using the fuel with the following modifications: (i) increasing the heat input by 10\%, (ii) increasing the heat input by $20 \%$.

\section{Results and discussion}

Figure 6 shows demonstrates the experimental behavior of firing rate fluctuations over time at normal operation and at changing the heat input by increasing $10 \%$ and $20 \%$.

Figure 7 Presents an experimental drum pressure behavior with time during normal operation while Figure 8 explains how the pressure in the drum behaves when a sudden increase in heat input $Q$. When the firing rate is at its highest, the drum pressure increases, allowing the firing rate to reach the mean by (2.1) minute due to an increase in heat input. As a result of a $10 \%$ step increase in the heat supply, the pressure increases at a steady rate of $d p / d t=0.0314$ bar/s. And the rate of pressure increases by $0.065 \mathrm{bar} / \mathrm{s}$ in the case of a $20 \%$ step increase in the heat supply. To explain the increase in drum pressure, when the firing rate rises, the amount of water volume inside the upper drum boiler rises as well, causing a disturbance (oscillation) in the drum pressure, indicating that the disturbance value in the minimum firing rate is less than the maximum firing rate.

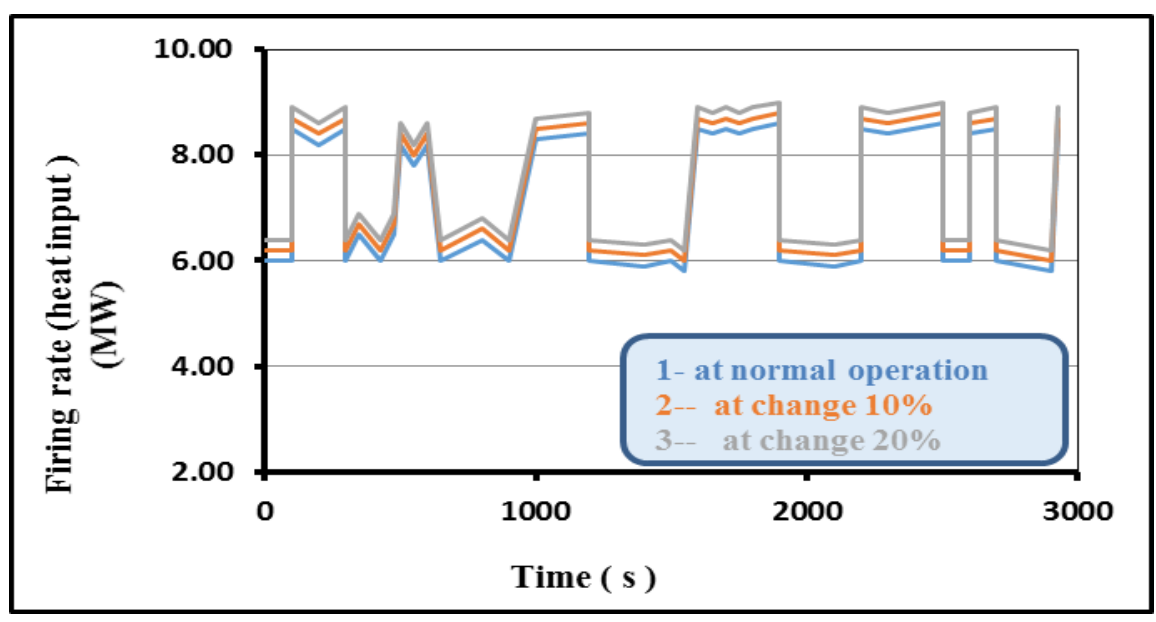

Figure 6: The experimental measurements for distribution firing rate 


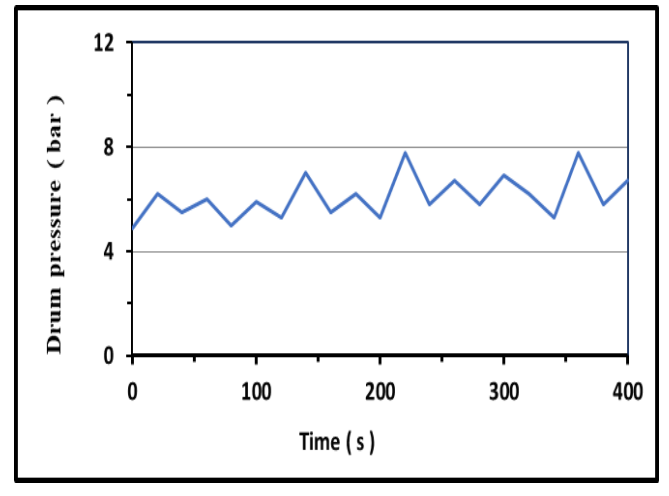

Figure 7: The drum pressure at normal operation in (Al-Quds power plant) in Baghdad / Iraq

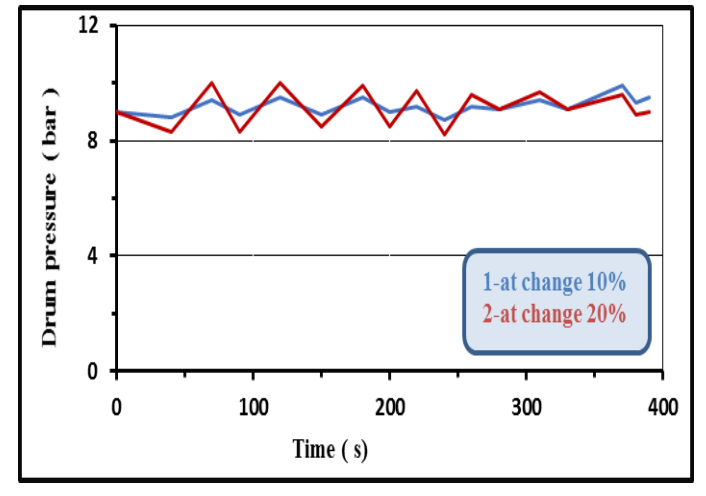

Figure 8: Reaction of drum pressure at min. and max. Fuel fire rate in (Al-Quds power plant) in Baghdad / Iraq

In the upper drum, there is a large amount of water and steam bubbles. During a quick increase in the steam load, a substantial rise in the water/steam level may occur due to an increase in the volume of these bubbles. The increase in volume was influenced by a decrease in steam pressure due to the increased load, as well as a rise in steam production due to the increased rate of fuel firing to match the increased steam load.

Figure 9 Shows steam- water level at regular operation with fuel firing rate, where the change in fuel firing rate has an influence on drum level, but rapid changes in drum pressure that expand or shrink the steam bubbles due to load changes are the most important cause of shrinkage and swelling. The drum pressure rises and the firing rate changes when there is a decrease in steam demand, if the pressure of the drum decreases, the boiling point of the water in the drum and the evaporator also decreases. This reduces the volume of the bubbles (i.e., bubbles get smaller). The water in the drum is actually forced up by the rising bubbles to create more bubbles.

Figure 10 shows the steam quality in the boiler, as the rate of evaporation rises in tandem with the increase in heat supply, the steam quality at the riser's exit improves. During the first 10 seconds, the output improves rapidly.

Figure 11 shows that the amount of water in the system has increased ( $V_{w t}$ increases). The rise in $V_{w t}$ is due to the rise in $V_{w d}$ as well as the condensation of steam under the water level in the drum. The growth in water content is in line with the increase in total water volume, $V_{w t}$.

Figure 12 shows the amount of steam according to the relationship [ $V_{s t}+V_{w t}=V$ ], the overall steam capacity, $V_{s t}$, decreases. Where V denotes the system's total volume.

Figure 13 demonstrates the influence on swelling phenomena of the rapid change of steam load. It is clear that when the steam load suddenly changes, the effects of swelling phenomena are increased and that the complex disruption in the watersteam level is increased.

Figure 14 demonstrates the influence on shrinking phenomena of the rapid change of steam load. It is clear that when the steam load suddenly changes, the effects of shrinking phenomena are increased and that the complex disruption in the watersteam level is increased.

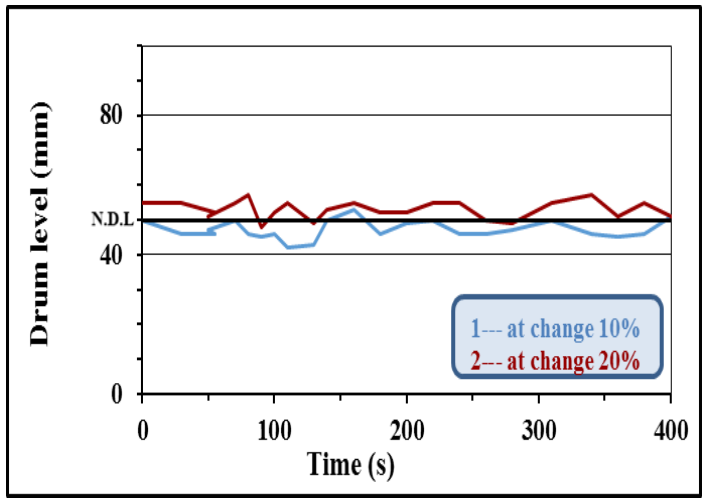

Figure 9: The Drum water level (Al-Quds power plant) in Baghdad / Iraq. When the fire rate (heat input) changes by 10 percent \& 20 percent at the normal operator

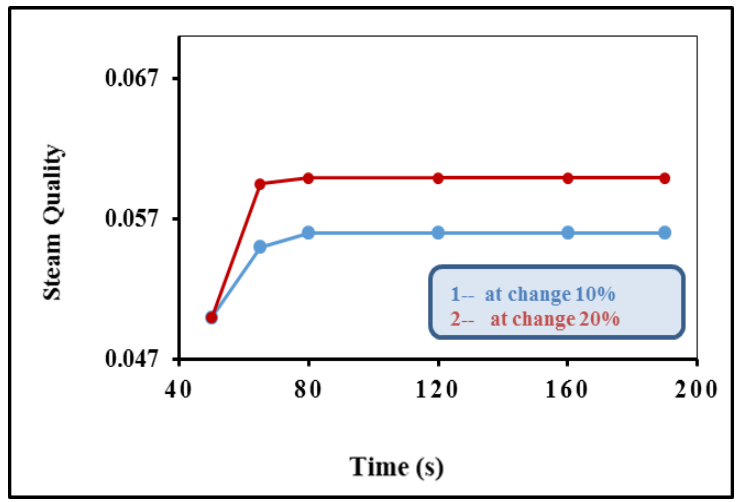

Figure 10: Variation of steam quality for step rise in heat input 


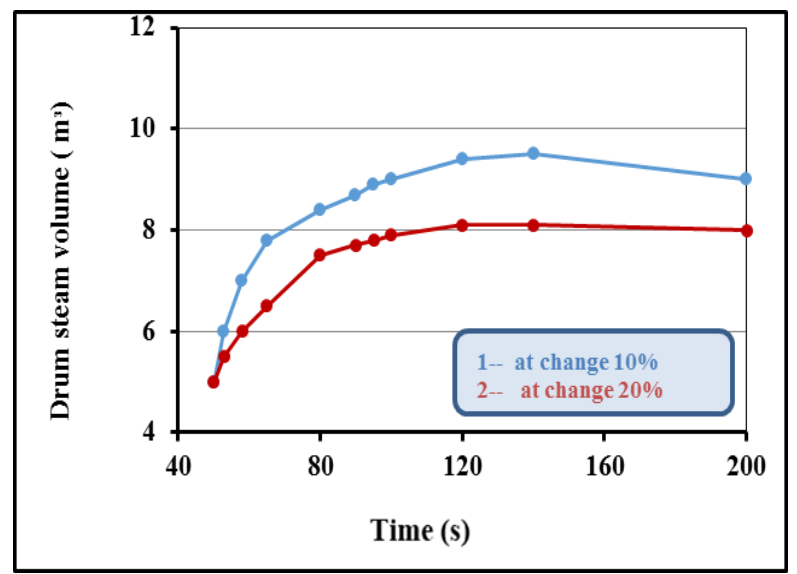

Figure 11: Variation of steam volume for step rise in heat input.

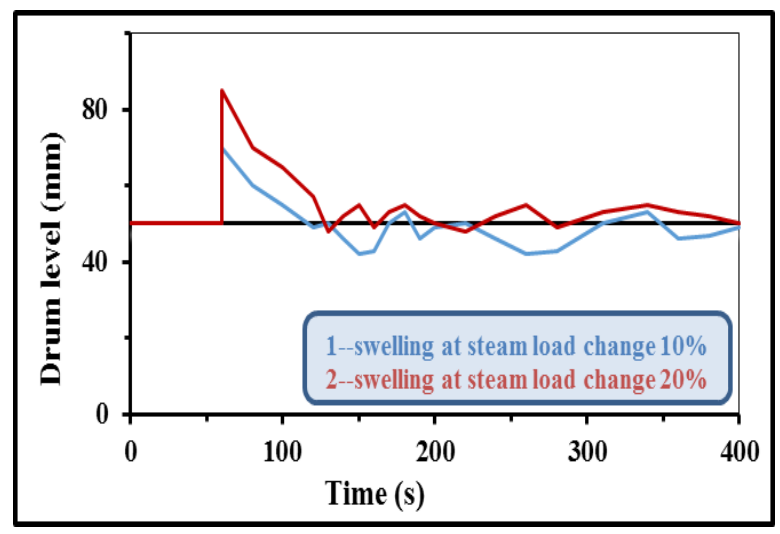

Figure 13: Effect of suddenly change of the load on swelling phenomena

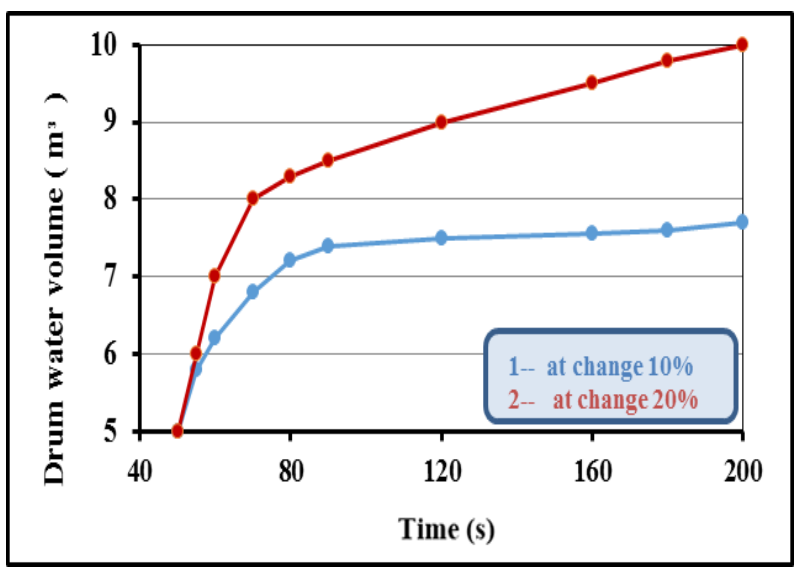

Figure 12: Variation of water volume for step rise in heat input.

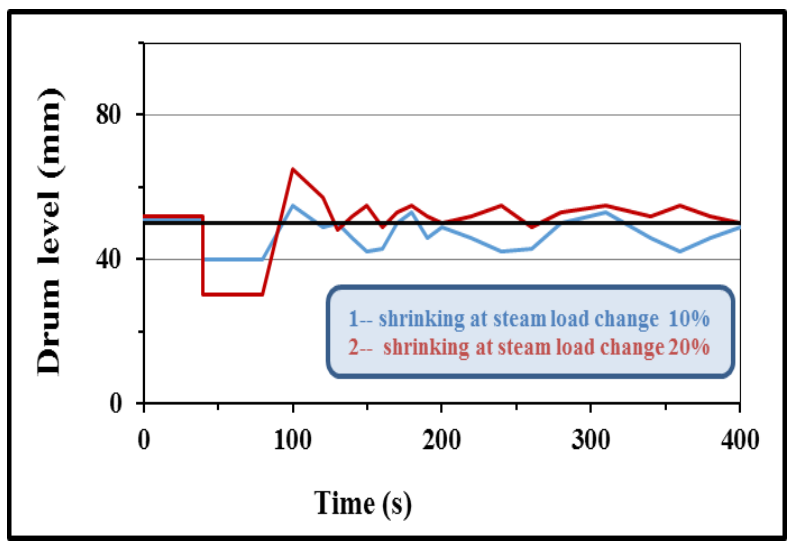

Figure 14: Effect of suddenly change of the load on shrinking phenomena.

\section{Acknowledgment}

The authors acknowledge the help received from (Al-Quds power plant staff) in Baghdad / Iraq to allow conduct experiments at the plant and provide assistance for experimental work.

\section{Author contribution}

All authors contributed equally to this work.

\section{Funding}

This research received no specific grant from any funding agency in the public, commercial, or not-for-profit sectors.

\section{Data availability statement}

The data that support the findings of this study are available on request from the corresponding author.

\section{Conflicts of interest}

The authors declare that there is no conflict of interest.

\section{Conclusions}

The current study looks at the dynamic consequences of rapid changes in steam mass flow rate (10\% and $20 \%)$ at the water tube boiler's outlet, the results indicate that:

1) A sudden rise in the loaded steam causes an increase in the upper drum's shrinking and swelling phenomena, when the temperature has increased, then the bubbling increases the volume of the drum and the level will first go up, and then the level begins to go down as the steam flow increases.

2) Due to the inverse response of the level to changes in steam demand, the drum level is hard to control.

3) To prevent overheating of the tubes, the drum level system must ensure that the water levels are always mainlined above the top of the risers/down comers. 
4) Drum level fluctuations cause interactions with the controls of boiler combustion and can generate cyclical or even unstable boiler control, resulting in inefficient and dangerous operations.

5) If the level of the drum drops too low, the boiler may be damaged by thermal stress.

6) If the level gets too high, some water particles may be carried by steam leaving the drum, which can cause harm to turbines or other steam users.

7) The future perspective is to use a control system to reduce the dynamic effects and improve the performance of the upper drum boiler.

Symbols

\begin{tabular}{|c|c|c|}
\hline$A_{d}$ & drum area at normal operating level & $m^{2}$ \\
\hline$C_{p}^{u}$ & specific heat at constant pressure & $\mathrm{KJ} / \mathrm{kg} . \mathrm{k}$ \\
\hline$h_{f}$ & specific enthalpy of saturated liquid water & $\mathrm{KJ} / \mathrm{kg}$ \\
\hline$h_{g}$ & specific enthalpy of saturated water vapor & $\mathrm{KJ} / \mathrm{kg}$ \\
\hline$h_{w}$ & specific enthalpy of feed water & $\mathrm{KJ} / \mathrm{kg}$ \\
\hline $\mathrm{L}$ & The drum water level & $\mathrm{m}$ \\
\hline$L_{s}$ & $\begin{array}{l}\text { Variations in the level causes by changing of the amount of the steam in } \\
\text { the drum }\end{array}$ & $\mathrm{m}$ \\
\hline$L_{w}$ & $\begin{array}{l}\text { Variations in the level causes by changing of the amount of the water in } \\
\text { the drum }\end{array}$ & $\mathrm{m}$ \\
\hline$m_{s}^{\prime}$ & mass flow rate of steam exiting the boiler to the super heater and turbine & $\mathrm{Kg} / \mathrm{s}$ \\
\hline$m_{w}^{0}$ & mass flow rate of feed water & $\mathrm{Kg} / \mathrm{s}$ \\
\hline$Q^{\cdot}$ & heat flow rate & $\mathrm{KJ} / \mathrm{h}$ \\
\hline$T_{s}$ & saturation temperature for steam & $\mathrm{C}^{0}$ \\
\hline$V_{w t}$ & Total volume of water in drum & $\mathrm{m}^{3}$ \\
\hline$V_{s t}$ & Total volume of steam in drum & $\mathrm{m}^{3}$ \\
\hline$V_{s d}$ & The volume of steam in drum & $\mathrm{m}^{3}$ \\
\hline$V_{w d}$ & The volume of water in drum & $\mathrm{m}^{3}$ \\
\hline$\rho_{f}$ & density of saturated liquid & $\mathrm{Kg} / \mathrm{m}^{3}$ \\
\hline$\rho_{g}$ & density of saturated steam & $\mathrm{Kg} / \mathrm{m}^{3}$ \\
\hline$\rho_{w}$ & density of water & $\mathrm{Kg} / \mathrm{m}^{3}$ \\
\hline$\rho_{f g}$ & Difference between vapor and liquid & \\
\hline
\end{tabular}

\section{References}

[1] S. R. Tawfeic, Boiler drum-level modeling, JES. J. Eng. Sci., 41 (2013) 1812-1829.

[2] A. S. E. Din Ahmed, M. A. Elhosseini, H. Arafat Ali, Modelling and practical studying of heat recovery steam generator (HRSG) drum dynamics and approach point effect on control valves, Ain Shams Eng. J., 9 (2018) 3187-3196. https://doi.org/10.1016/j.asej.2018.06.004

[3] R. Wohlfarth, A. L. Kohan, Boiler operator's guide, McGraw-Hill Education, 2021.

[4] S. Kim, S. Choi, T. H. Song, J. Lappalainen, Dynamic simulation study of the steam temperature in a ultra-supercritical circulating fluidized bed boiler system, Proc. Inst. Mech. Eng. A: J. Power Energy, 235 (2020). https://doi.org/10.1177/0957650920915304

[5] W. Zima. Simulation of rapid increase in the steam mass flow rate at a supercritical power boiler outlet, 173 (2019) 9951005.

[6] S. Ardi, S. Fairus, S. Sukmaningrum, Design Control and Monitoring System for Boiler Wastewater Treatment Process Using Programmable Logic Controller and Hmi (Human Machine Interface), Sinergi, 24 (2020) 133. https://doi.org/10.22441/sinergi.2020.2.007

[7] X. Zhu, W. Wang, L. Mu, Q. Bi, Theoretical analysis on response characteristics of mass flow in supercritical pressure circulating fluidized bed boiler, Appl. Therm. Eng., $87 \quad$ (2015) 286-296. https://doi.org/10.1016/j.applthermaleng.2015.04.080

[8] K. G. Bilde, K. Sørensen, and T. Condra, Mathematical model of natural circulation biomass boilers during start-up, Int. J. Heat Mass Transf., 143 (2019) 118477. https://doi.org/10.1016/j.ijheatmasstransfer.2019.118477

[9] M. A. Habib, H. E. Emara-Shabaik, I. Al-Zaharnah, T. Ayinde, A thermal nonlinear dynamic model for water tube drum boilers, Int. J. Energy Res., 34 (2010) 20-35. https://doi.org/10.1002/er.1548 
[10] B. Hemalatha, J. A. Vimala, N. Natarajan, Boiler Level Control using LabVIEW, Int. J. Comput. Appl., 1 (2010) 85-88. https://doi.org/10.5120/356-540

[11] C. Sreepradha, R. C. Panda, N. S. Bhubaneswari, Mathematical model for integrated coal fired thermal boiler using physical laws, Energy, 118 (2017) 985-998. https://doi.org/10.1016/j.energy.2016.10.127

[12] A. F. Halihal, Modeling and control of water level in boiler drum for nassiriyah thermal power plant, Iran. J. Electr. Electron. Eng., 15 (2019) 229-242.

[13] http://www.mech-engineeringbd.blogspot.com/2016/07/water-level-indicator.html.

[14] M. Iacob, G. Andreescu, Drum-boiler control system employing shrink and swell effect remission in thermal power plants, 2011 3rd International Congress on Ultra-Modern Telecommunications and Control Systems and Workshops (ICUMT), IEEE, 2011.

[15] M. A. Habib, I. Alzaharnah, M. El-Shafei, S. Al-Anizi, M. Y. Al-Awwad, M. Hajji, Influence of Boiler Load Swing Rates on Response of Drum Water Level, ASME J. Energy Res. Technol. ASME, 135

022904. https://doi.org/10.1115/1.4023329

[16] S. B. Savargave, M. J. Lengare, Modeling and optimizing boiler design using neural network and firefly algorithm, Int. J. Intell. Syst. 27 (2018) 393-412, 2018. https://doi.org/10.1515/jisys-2016-0113

[17] A. Kouadri, A. Namoun, M. Zelmat, Modelling the nonlinear dynamic behavior of a boiler-turbine system using a radial basis function neural network, Int. J. Robust Nonlinear Control, 24 (2014) 1873-1886. https://doi.org/10.1002/rnc.2969

[18] Z. Wiesław, Simulation of steam superheater operation under conditions of pressure decrease, Energy, 172 (2019) 932-944. https://doi.org/10.1016/j.energy.2019.01.132

[19] M. A. Habib, H. E. Emara-Shabaik, I. Al-Zaharnah, and T. Ayinde, A thermal nonlinear dynamic model for water tube drum boilers, Int. J. Energy Res. 34 (2010) 20-35. https://doi.org/10.1002/er.1548 